\author{
اثر مقادير مختلف نانورس مونتموريلونيت بر تغييرات رواناب و هدررفت خاك

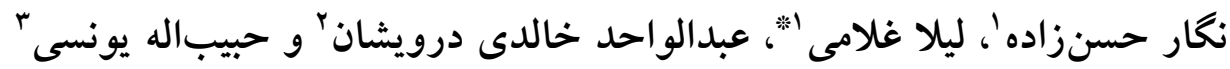

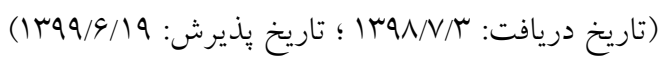

جكيده

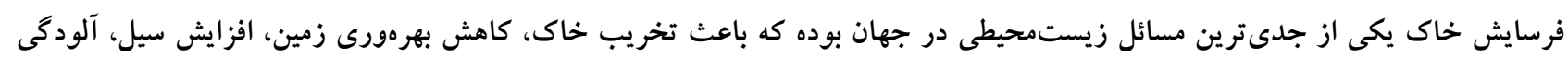

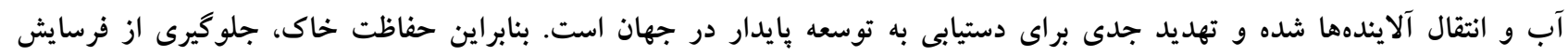

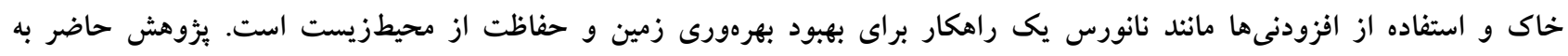

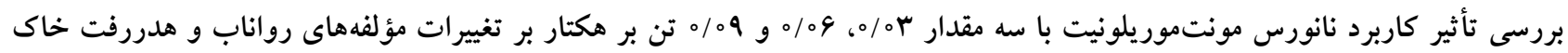

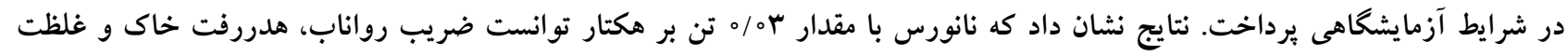

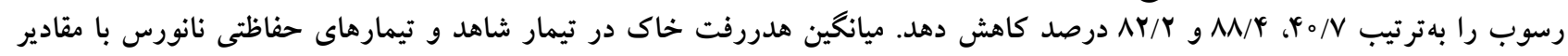

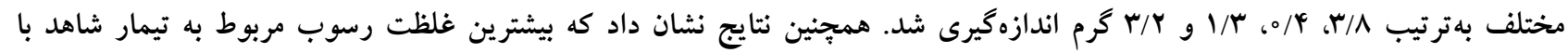

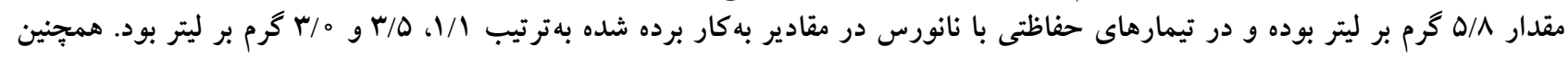

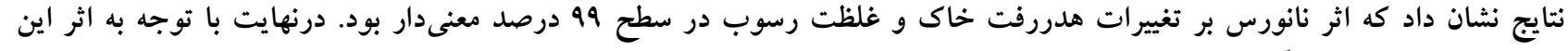

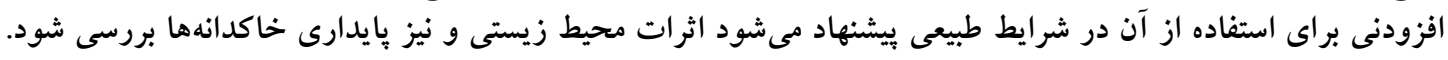

وازههاى كليدى: افزودنىهاى نوظهور خاك، حفاظت آب و خاك، غلظت رسوب، فرسايش خاك

ا. كُروه مهندسى آبخيزدارى، دانشكدة منابع طبيعى دانشخاه علوم كشاورزى و منابع طبيعى سارى، سارى، ايران

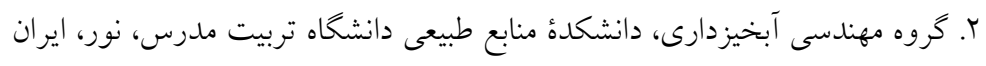

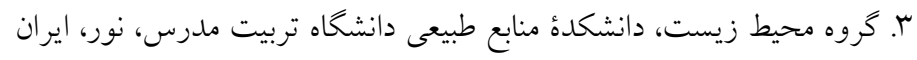

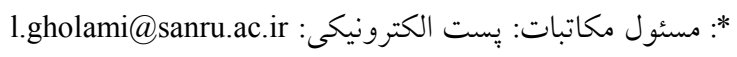


شيميايى) از جمله كاه و كلش، كود دامسى، كميوسـت و ورمسى

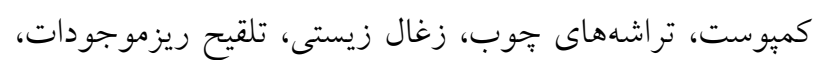

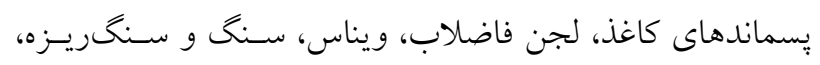

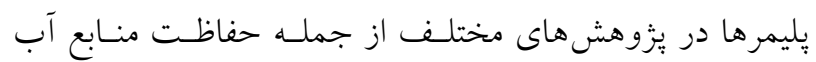

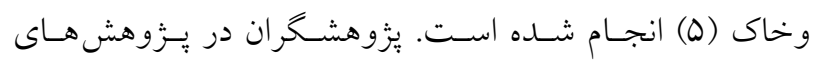

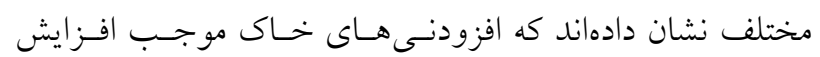

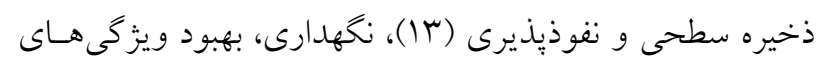

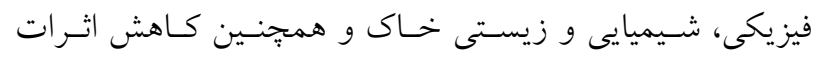

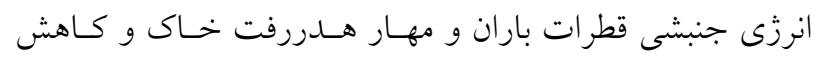

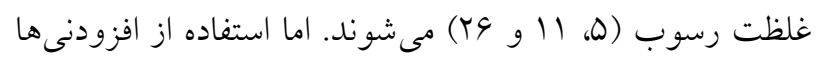

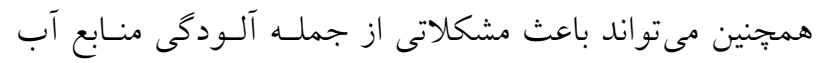

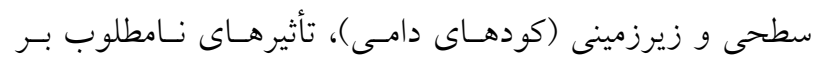
موجودات خاك (سويرجاذب TA-200)، رشد علفهــاى هـرز

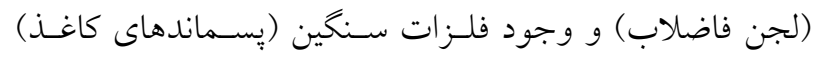

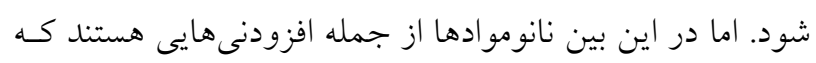

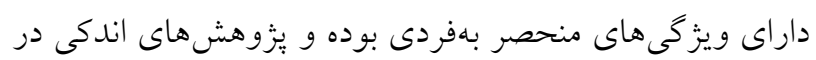

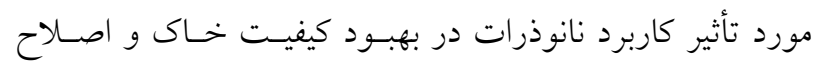

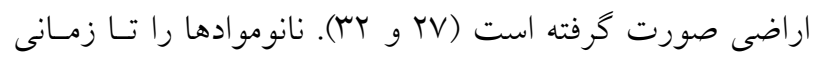

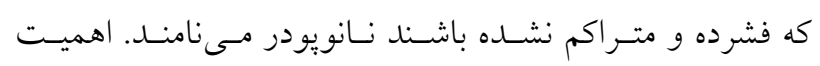

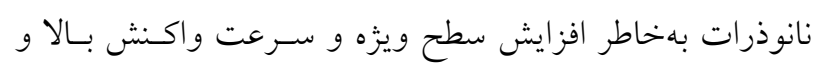

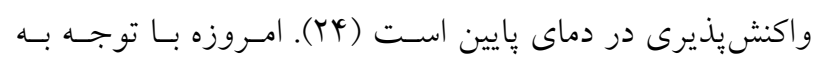

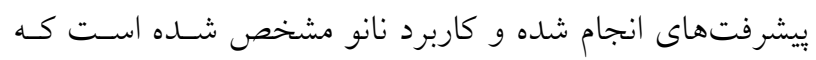

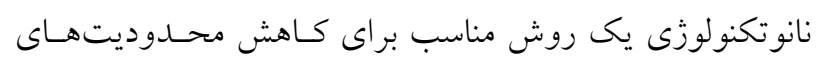

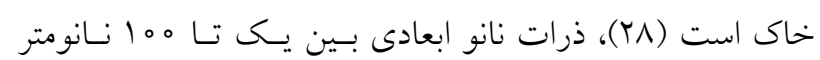

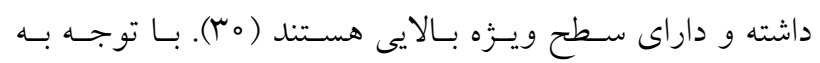

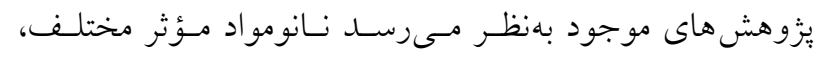

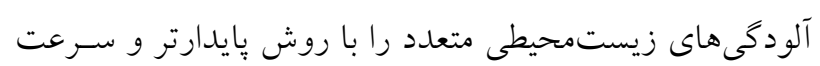

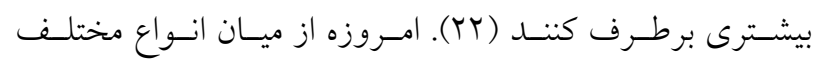

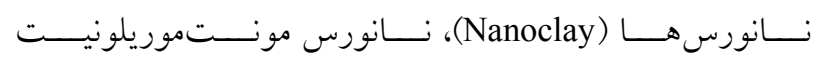
بهدليـل داشـتن ظرفيـت تبــادل (Montmorillonite Nanoclay) كاتيونى و تخلخل بيشتر، كاربرد زيادترى بيدا كرده اسـت (1). همجنين كانى هاى رس بهدليل بايدارى شيميايى و مكانيكى بالا،

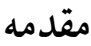

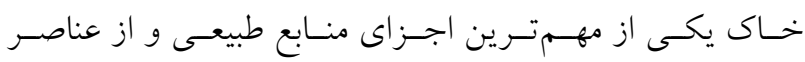

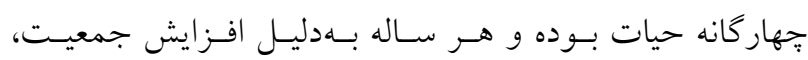

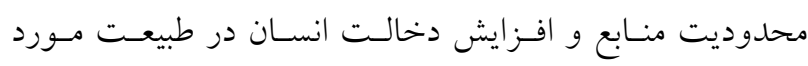

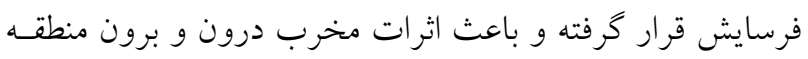

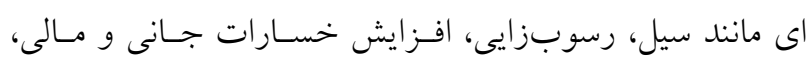

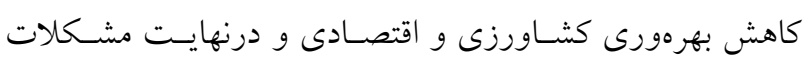

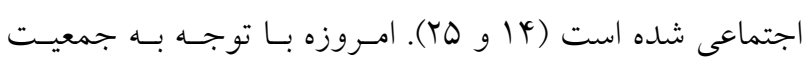

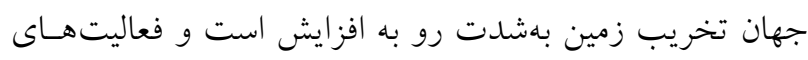

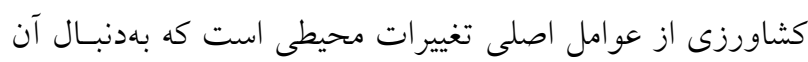

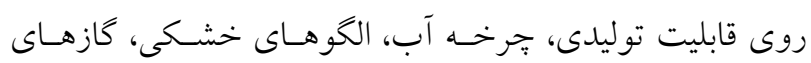

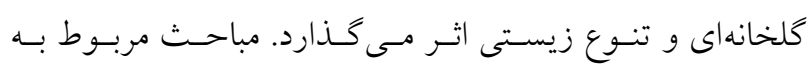

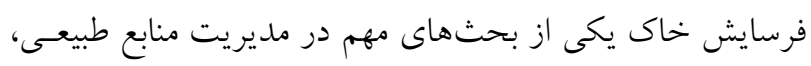

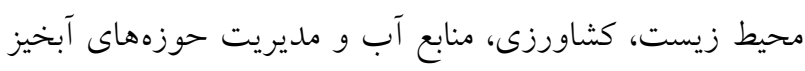

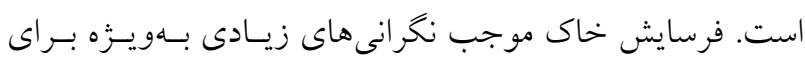

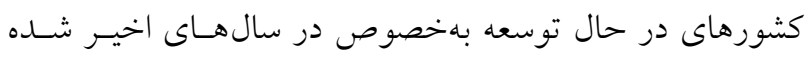

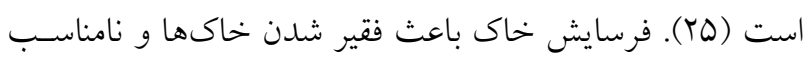

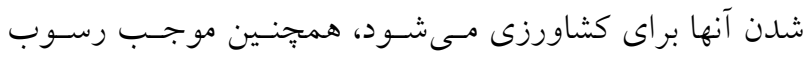

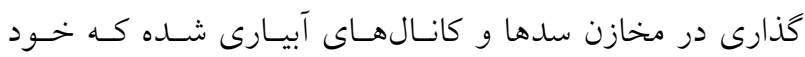

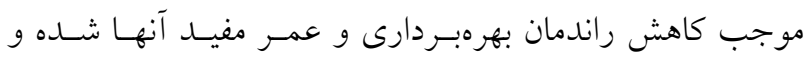

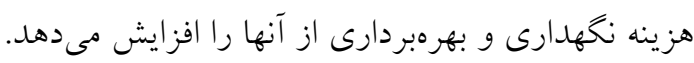

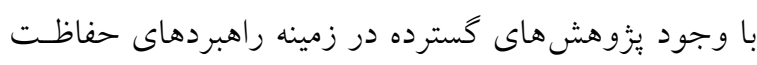

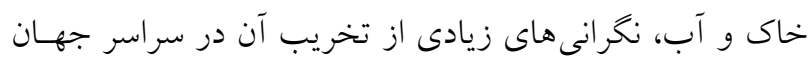

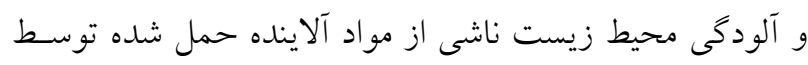

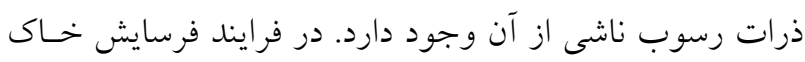

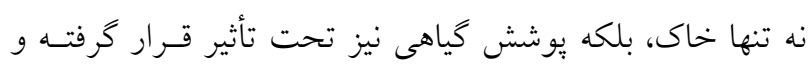

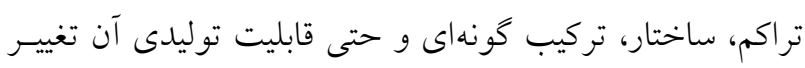

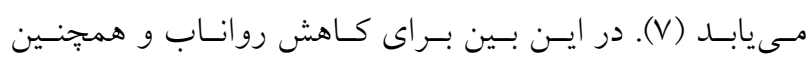

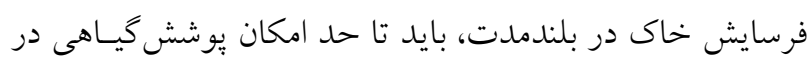

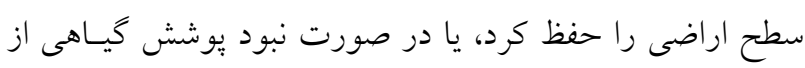

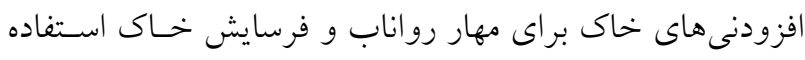

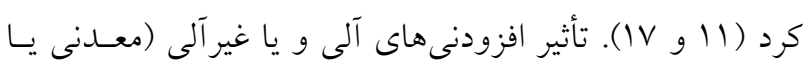


و هفت روزه بر بر اكندكى دو نوع خـاك را بررسى كردنـــ آنها بيان كردند كه افزودن نانورس به خاكهاى مورد استفاده، بتانسيل

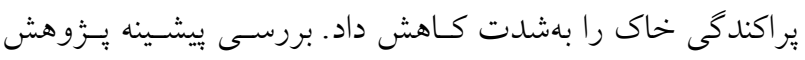

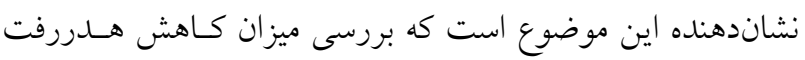

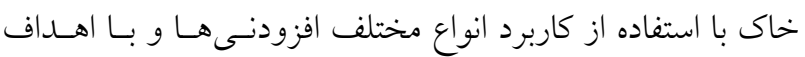

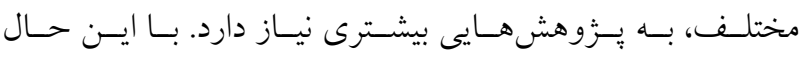
محدوديتهـاى محسيط زيستى، زمـانبر بـودن و اثربخشى كـم، كاركرد افزودنىها در شكل معمول را با جالش مواجه كرده است. اما مىتوان بيان كرد كه نانورس بهعنـوان يـك افزودنى نوظهـور براى حفاظت خاك و آب قابل استفاده است و همجنِنين دسـتيابى به مقدار بهينه از كاربرد اين افزودنى در راستاى اهـداف حفاظـت فئس خاك و آب در فرسايش آبى داراى اهميت بوده كه تاكنون بـه آن يرداخته نشده است. از سويى ديخر بايستى مفــار بهينـهاى بــراى

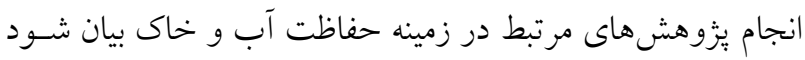

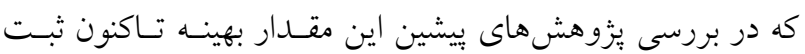

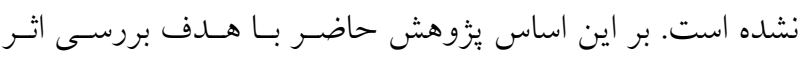

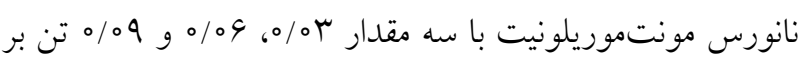

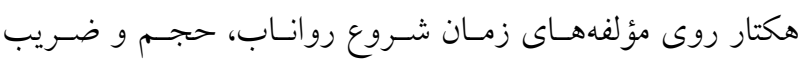

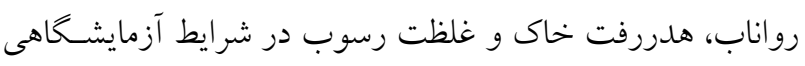

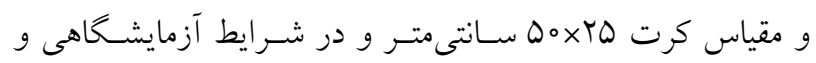

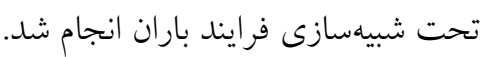

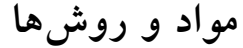
خاك منطقه مورد مطالعه و آمادهسازى خاى

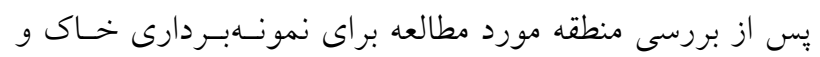

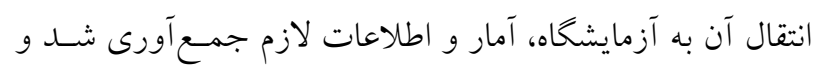

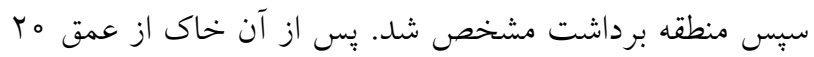

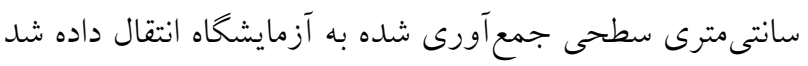

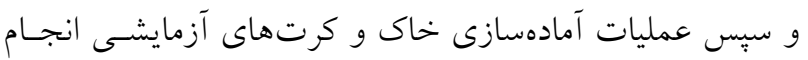
شد. خاك مورد نظر از مراتع ييلاقى كجور نوشهر بـا مختصـات

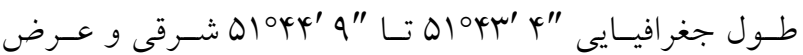

تنوع زياد در نوع، ارزان بودن، سطح ويزه بالا و قـدرت جـــب

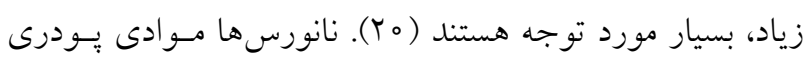

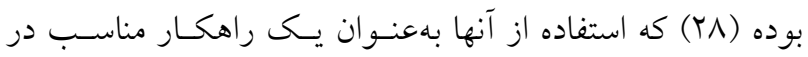

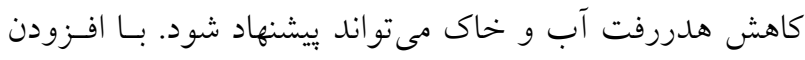

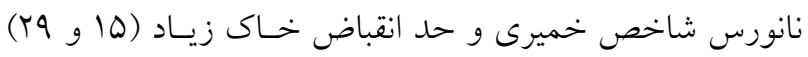
مىشود. نانورس بهدليل داشتن مساحت سطح ويزه بسيار حتى ونى

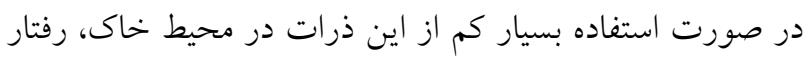

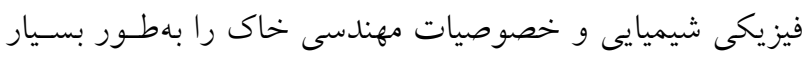

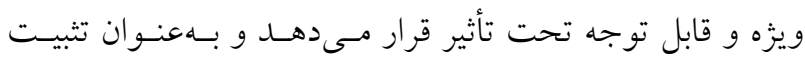

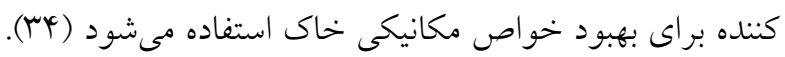

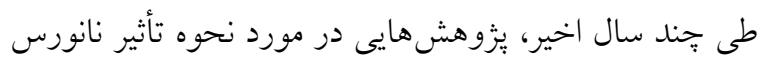
مونتموريلونيت انجام شده است كه بهصورت مختصـر در ادامـهـ ارائه شده است. كنعانىزاده و خوشنيت (r) (I) در ايران به بررسى

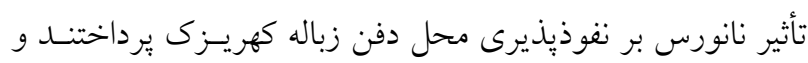

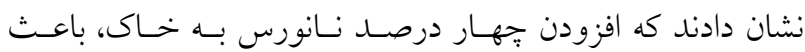

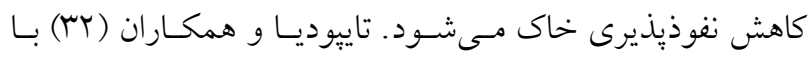

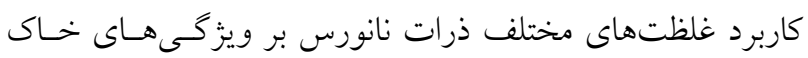

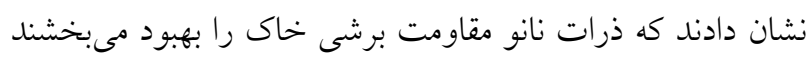

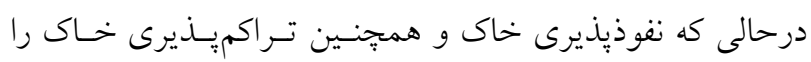

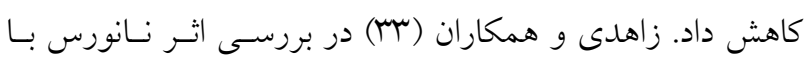

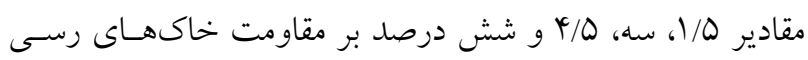

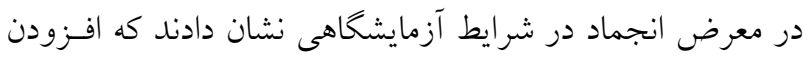
نانوذرات باعث كاهش استحكام خاك طى دوره انجماد مىشـود.

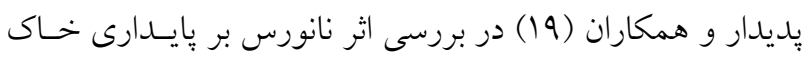

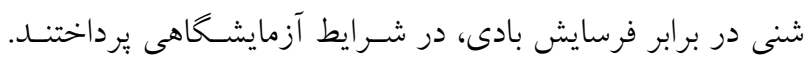

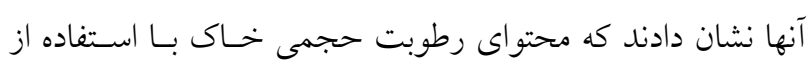

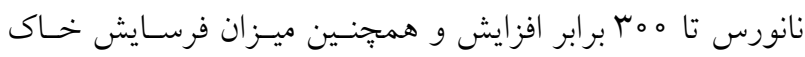
بيش از 99 درصد كاهش يافت. هاتفى و همكاران (1) بـا كـاربرد

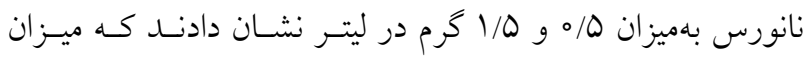

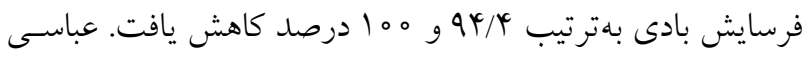

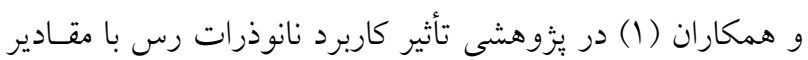

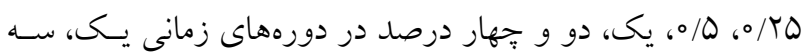


جدول ا. ويزگى هاى فيزيكى و شيميايى نانورس

\begin{tabular}{|c|c|c|c|c|c|c|c|c|}
\hline \multicolumn{2}{|c|}{ رطوبت } & & فين ذاصله خالى & ضريب تبادل يونى (ميلى الان در المرم) & \multicolumn{2}{|c|}{ مساحت سطح ويزه } & اندازه ذرات & 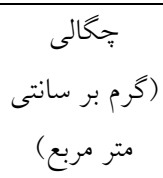 \\
\hline & & زرد كمرنگ & $9 \circ A^{\circ}$ & 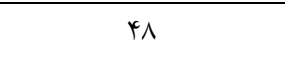 & & & $1-r$ & $\circ / 0-\circ / V$ \\
\hline \multicolumn{9}{|c|}{ تركيب شيميايى (درصد) } \\
\hline LOI & $\mathrm{Fe}_{2} \mathrm{O}_{3}$ & $\mathrm{TiO}_{2}$ & Cao & $\mathrm{K}_{2} \mathrm{O}$ & $\mathrm{SiO}_{2}$ & $\mathrm{Al}_{2} \mathrm{O}_{3}$ & $\mathrm{MgO}$ & $\mathrm{Na}_{2} \mathrm{O}$ \\
\hline $10 / 40$ & D/GY & $0 / 94$ & $1 / 9 V$ & ०/AG & $0 . / 90$ & $19 / 90$ & $r / r q$ &.$/ 91$ \\
\hline
\end{tabular}

حاضر ساخته شدند. سيس براى شبيهسازى بهتر شرايط طبيعى كرتها تا ارتفاع ه ا سانتى مترى با بوكه معــنى يسر شــده و ه سانتى متر سطحى كرتهاى با خاك الك شده، ير شد. درنهايـت سطح كرتها بهمنظور شبيهسازى شرايط موجـود در طبيعـت و

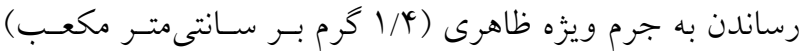
خاك در شرايط طبيعى، با غلتك مخصوص كوبيده شد (9). بعد از آن كرتها براى شبيهسازى شرايط رطوبـت بيشـين خـاك و متناسب با شرايط طبيعى، حدود ب أ ساعت تحت شرايط اشـباع از كف قرار كرفتند (شكل ا ) و بعد از آن كرتهاى آماده شـده بهمدت ب M ساعت رها شدند. درنهايت شبيهسازى آزمايش ها بـا استفاده از بارشى با شدت م\& ميلىمتر بر ساعت (بهدست آمـده از منحنىهاى شدت- مدت - فراوانى با استفاده از آمار ايستـاه سينويتيك كجور) براى مدت زمان مب دقيقه انجام شد. همجِنين بهمنظور انجام آزمايشها و برآورد شيب طبيعى و متوسط منطقه (ه)، كرتها روى سطوح شـيبدار بـا شـيب 11 الدرصـد قـرار

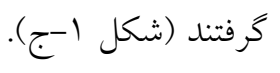

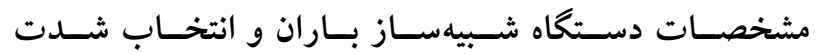
بارندگ

در يزؤهش حاضر از شبيهساز بـاران قابـل حمـل سـاخته شــه توسط بزّوهشخران بيشين (9) در دانشكده منابع طبيعى دانشخاه تربيت مدرس استفاده شد. سامانه آبرسانى آن شامل موتور بِمٍٍ

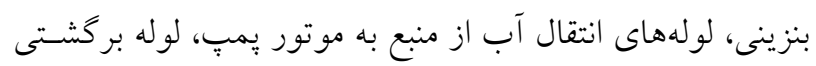

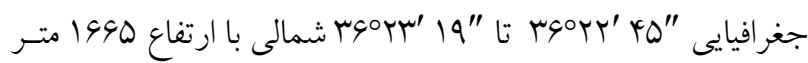
از سطح دريا برداشت شد. آزمايشهاى اوليسه خــاك نشـان داد كـهـ بافت آن شنى - لومى با مقادير رس، سيلت و شن بهترتيـب \\، با،

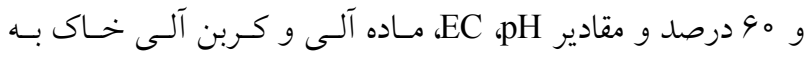

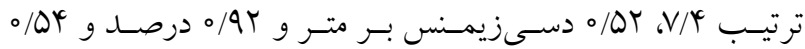
درصد بود. نانورس مونتموريلنيت در اين بزّوهش از نانورس صـنعتى خريــارى شـــه از شـركت

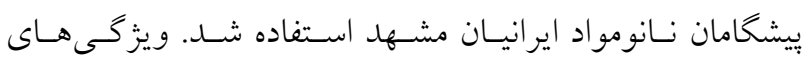
فيزيكى و مكانيكى و تركيب شيميايى اين نانورس در جـدول ا نشان داده شده است.

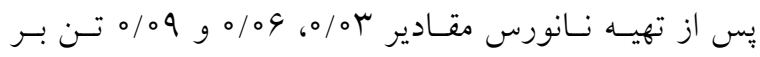
هكتار بهعنوان مقادير بيشنهادى بـراى انجـام يـرّوهش انتخــاب شدند. سيس نانوذرات مونتموريلنيت با استفاده از الك ( آY) و بهصورت يكنواخت در سطح كرتها يخش شده و آزمـايشهـا براى تيمار شاهد (بــون نـانورس مونستموريلونيـت) و تيمـار حفاظتى (با استفاده از نانورس مونتموريلونيـت در سـه سـطح مصرفى تعريف شده) در سه تكرار انجام شد.

آمادهسازى كرتهاى فرسايش

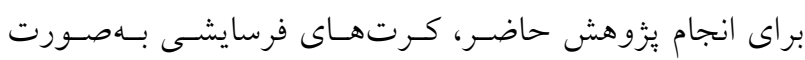

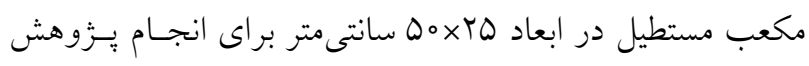




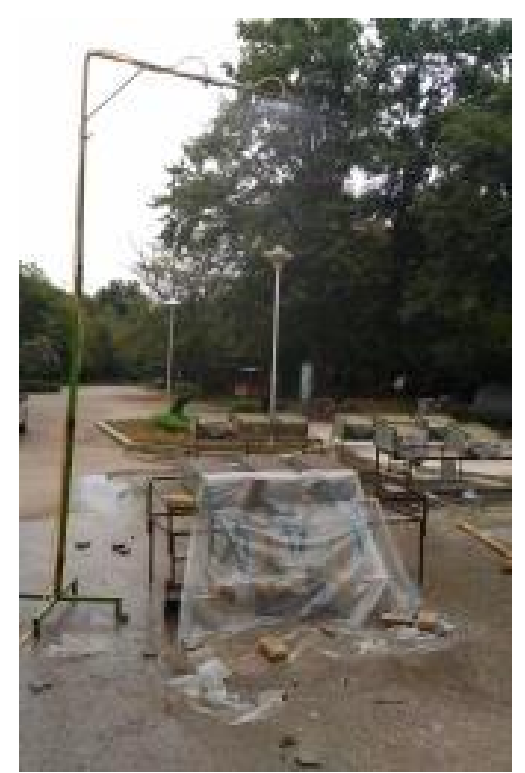

(ج)

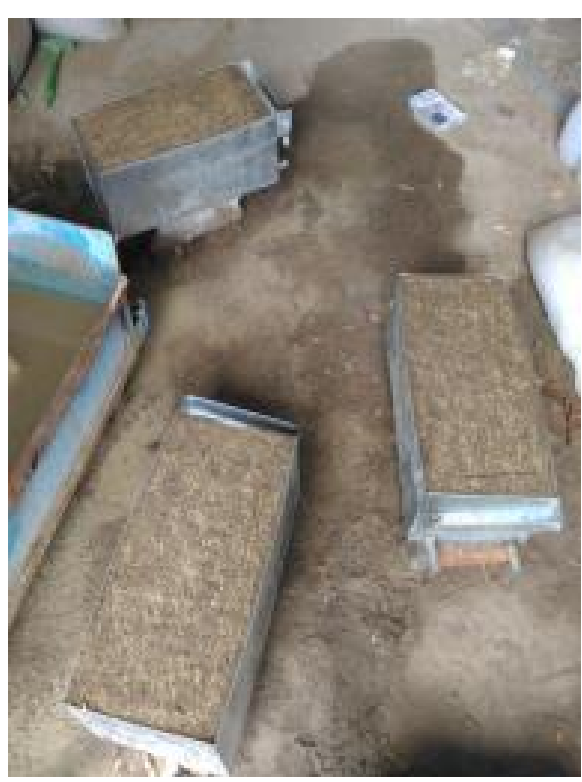

(ب)

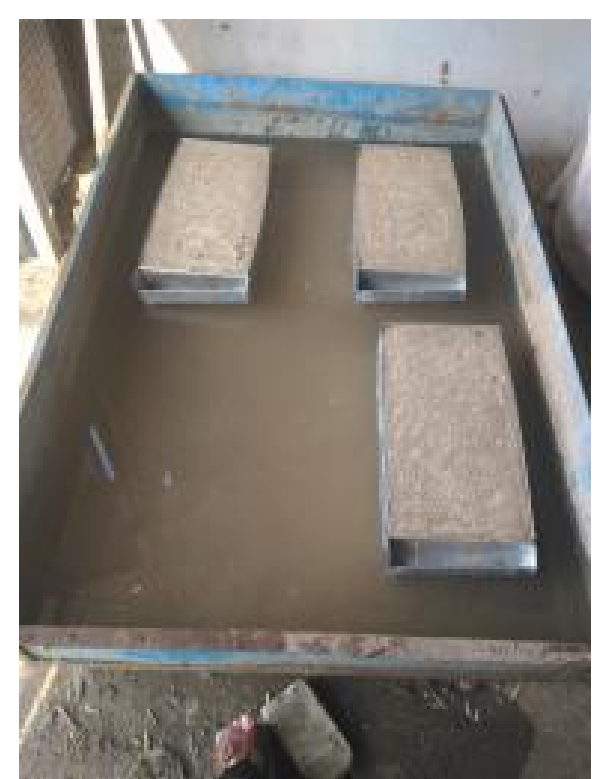

(الف)

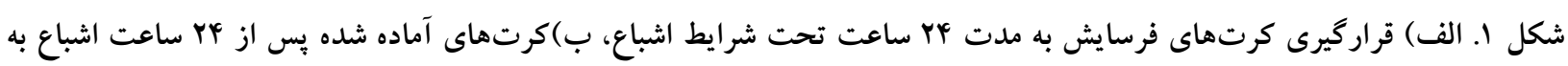

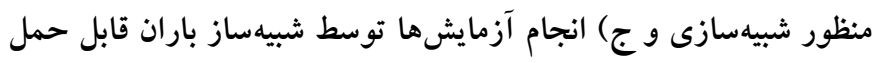

جداكانه براى هر كرت (شاهد و حفاظـت شـده) جمـع آورى و

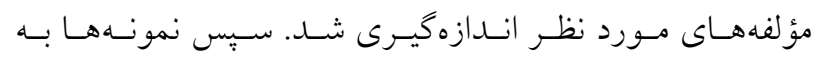

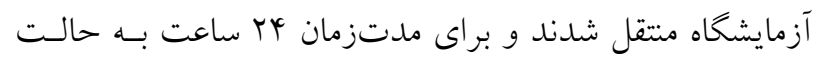
سكون قرار داده شد، بس از مدت زمان مورد نظر، با استفاده از روش تغليظ (ه و 9) اقدام به تخليه آب اضافه كرده و درنهايت نمونههاى رسوب در آون با دماى هه إ درجه سانتى گراد بهمدت

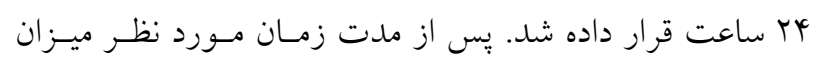

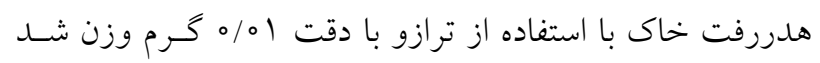
(9 و و (Y). براى تجزيه و تحليل دادهها ابتدا نرمال بودن دادههاى

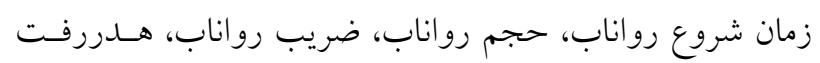
خاى و غلظت رسوب در تيمارهاى شاهد، تيمارهاى حفاظتى با

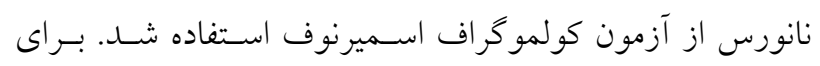

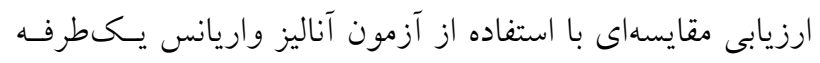
در محيط نرمافزار SPSS و بــا اسـتفاده از مـــل خطى عمـومى انجـام شـود. سـيس بـراى (General Linear Model (GLM)) مقايسه ميانكين مقادير تيمارها از آزمون دانكن استفاده شود (Iال و سY). براى اندازه گيرى درصد تغييرات مؤلفههـاى مختلـف در

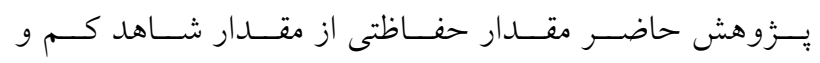

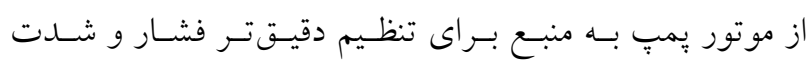

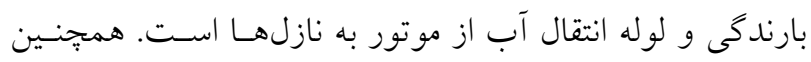
و سامانه مورد نظر داراى سه عدد نازل باران BEX: 3/8 S24W سه يايه براى رساندن نازلها به ارتفاع مناسب براى نزول بـاران

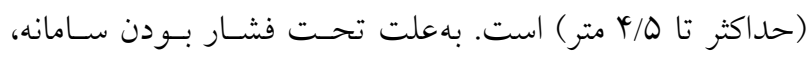

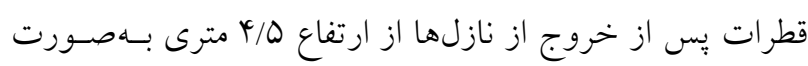

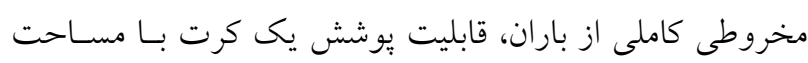

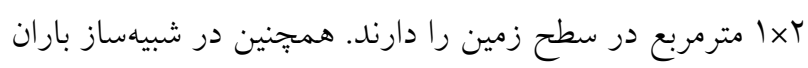
مورد نظر با تغيير ارتفاع و يا تعداد نازلهاى فعال، تنظيم فشـار

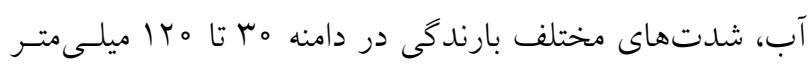
در ساعت قابل شبيهسازى است (9). براى انجام آزمـايشهـا در

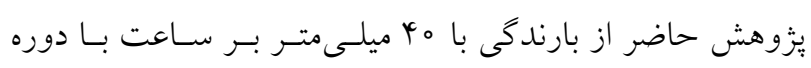

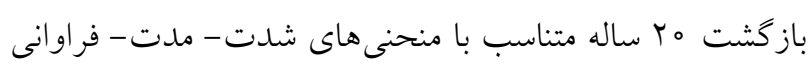
منطقه استفاده شد.

اندازهيرى مؤلفهها و تحليل دادهها يس از ثبت زمان شروع رواناب (ه و 9)، نمونههـاى روانـاب و

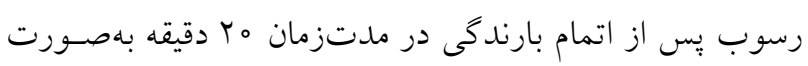


جدول r. زمان شروع رواناب، حجم رواناب، ضريب رواناب، هدررفت خاك و غلظت رسوب در تيمار شاهد و تيمار حفاظت شده با استفاده از كاربرد نانورس مونتموريلونيت در مقادير مختلف كاربردى

\begin{tabular}{|c|c|c|c|c|c|c|}
\hline غلظت رسوب & $\begin{array}{c}\text { هدررفت خاك } \\
\text { (كرم) }\end{array}$ & 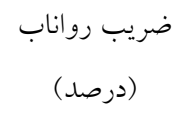 & حجم رواناب & زمان شروع & كرت & تيمار \\
\hline$Q / F Y$ & $4 / 9 \Lambda$ & $k \mu / 00$ & 190 & TY。 & 1 & \\
\hline V/VF & זת/ז & $r \mid / \Delta r$ & wro & rrv & r & شاهد \\
\hline$\varphi / \mu \Delta$ & $\Gamma / \tau \varphi$ & $\mathrm{rq} / \mathrm{vq}$ & $V Q 0$ & $10 \mathrm{~V}$ & r & \\
\hline Q/AF & r/vG & MY/VA & $91^{\circ}$ & rII & & ميانخين \\
\hline$r q / 9 \mathrm{~V}$ & $r|r|$ & $M \mu / T \Lambda$ & TY/AD & Tr & & ضريب تغييرات \\
\hline $1 / 41$ & $0 / 4 Q$ & $19 / 0 T$ & Mro & 190 & 1 & نانورس به مقدار \\
\hline $\mid / \mu 1$ & $\circ /{ }^{4}$ & $r q / T V$ & 090 & 190 & r & r r \\
\hline $0 / 41$ & $0 / 1 T$ & $19 / 14$ & $r 90$ & 119 & r & هكتار (MPN1) \\
\hline $1 / 04$ & $0 / 44$ & To/94 & r r & $19 \mathrm{~V}$ & & ميانخين \\
\hline$\Delta T / Q G$ & $V Y / \circ{ }^{c}$ & re/ro & rV/qr & TS & & ضريب تغييرات \\
\hline$\Lambda r / 19$ & $\Lambda M / \mu$ & $40 / 90$ & $K T / 1 G$ & YI & & درصد حفاظتى \\
\hline$y / 4 k$ & $1 / 4 T$ & $19 / 90$ & rYo & $M \Lambda$ & 1 & نانورس به مقدار \\
\hline$r / 94$ &.$/ 91$ & $19 / 94$ & M。 & $|4|$ & r & \% \\
\hline r/or & $1 / 9 \mathrm{~V}$ & $r q / \Lambda 9$ & $\Delta Q \circ$ & 1r4 & r & هكتار (MPN2) \\
\hline$r / \mu V$ & 1/1/ & TI/Or & r זמוז & lor & & ميانخين \\
\hline$Y Y / Y_{0}$ & $r q / \circ D$ & rG/Td & $M Y / Q T$ & rI & & ضريب تغييرات \\
\hline $4 \circ / 9 \pi$ & $94 / 01$ & $r q / 0 r$ & $F Y / 19$ & rA & & درصد حفاظتى \\
\hline r & $r / r q$ & $V 1 / 01$ & Irro & 179 & 1 & نانورس به مقدار \\
\hline $1 / v r$ & $1 / 19$ & re/OV & $q V_{0}$ & 119 & r & 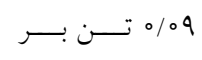 \\
\hline r/A & $r / q 4$ & $\Delta G / 4 \Lambda$ & lor. & $11 \pi$ & $r$ & هكتار (MPN3) \\
\hline$r / 99$ & r/l9 & $O F / \Lambda G$ & $1009 / 9 \mathrm{~V}$ & Iro & & ميانخين \\
\hline r4/99 & $\Delta Q / \Gamma_{0}$ & $r 1 / 90$ & סT/TM & v & & ضريب تغييرات \\
\hline$Y q / \mu 4$ & $10 / 29$ & $-Q V / V Y$ & $-\psi N / \circ \varphi$ & kr & & درصد حفاظتى \\
\hline
\end{tabular}

سبّ بر مقدار عدد شاهد تقسيم شد و درنهايت عـدد محاسـبه و ضريب رواناب، هدررفت خـاك و غلظـت رسـوب در تيمـار

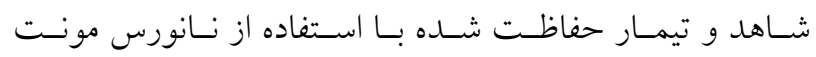

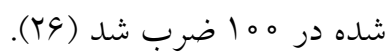

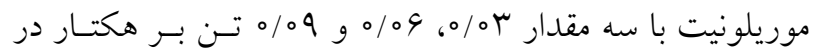

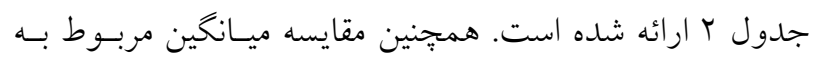

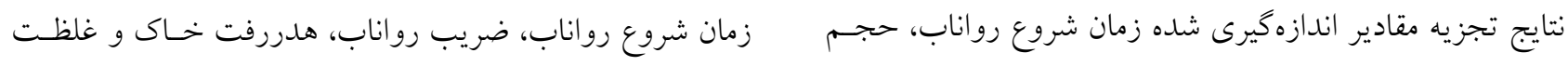



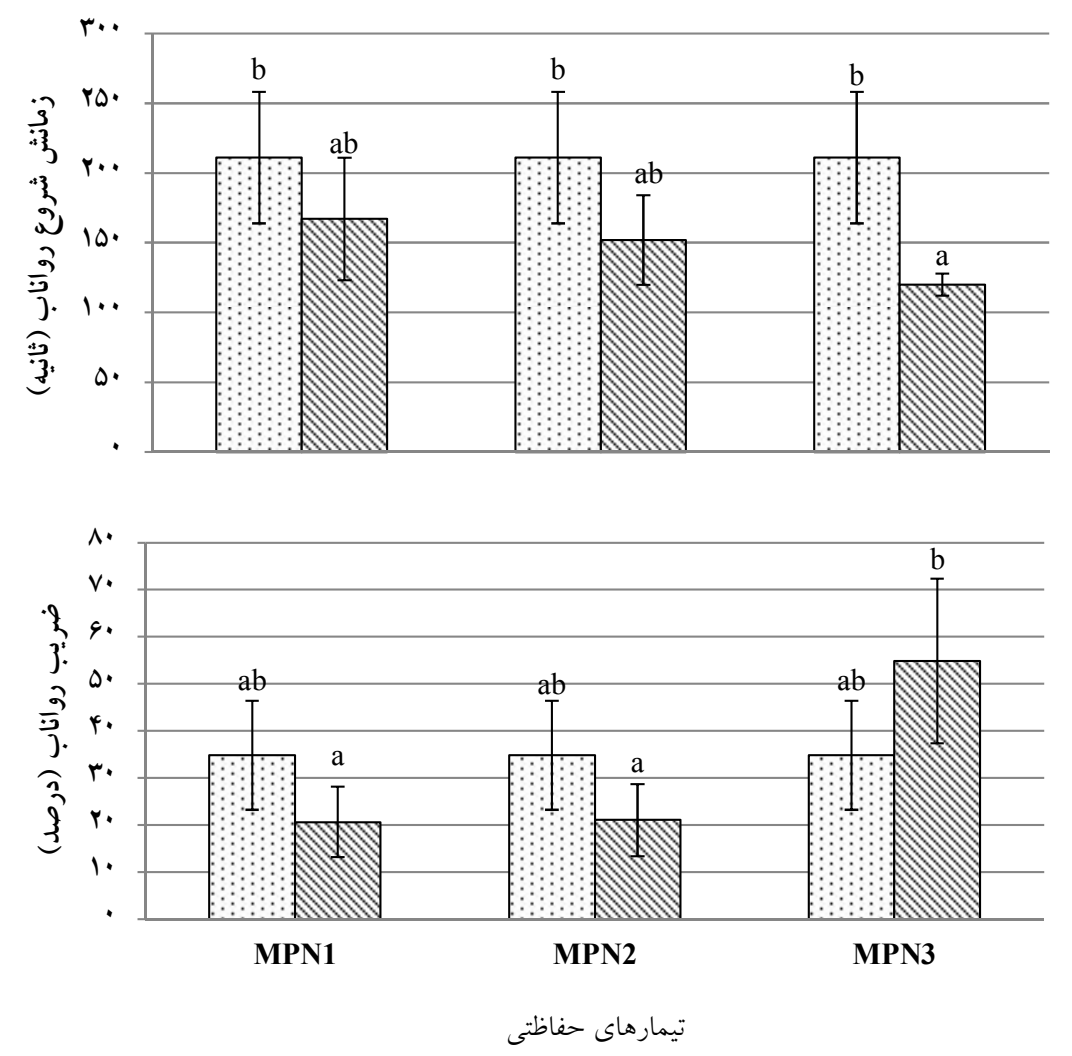

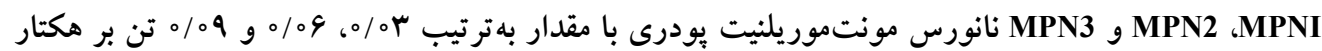

شكل r. الف) مقايسه ميانكين زمان شروع رواناب و ب) ضريب رواناب در تيمارهاى شاهد و نانورس مونتموريلونيت با مقادير مختلف

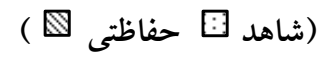

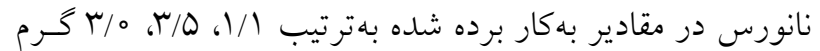
بر ليتر اندازه كيرى شد.

\section{بحث}

بررسى نتايج نشان داد كه بيشترين زمان شروع رواناب در تيمار شاهد رخ داد و بعد از كاربرد نانورس، ايسن افزودنسى نتوانسـت

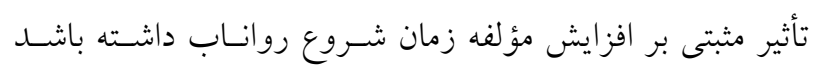

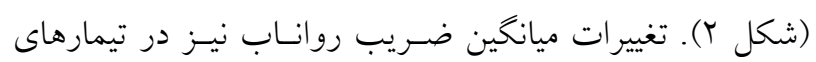

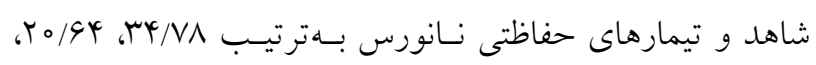

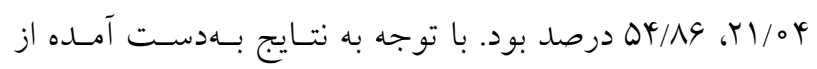
حجم رواناب مىتوان بيان كرد كه كمترين ميزان ضريب رواناب در تيمار حفاظتى نانورس به مقدار به/ تن بر هكتار نسبت بـه

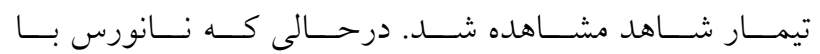

رسوب در تيمار شاهد و تيمارهاى نانورس مونتموريلونيت در شكل هاى Y و r ارائه شده است. نتايج حاصل از جدول r نشان مىدهد كه نانورس با مقادير مـورد اسـتفاده بـر تغيــرات زمـان شروع روانـاب، حجـم و ضـريب روانـاب، هـدررفت خـاك و

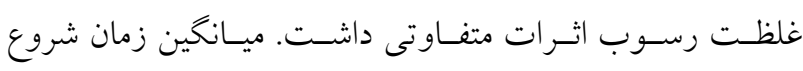
روانـاب در شدت ه † ميلـىمتر بر ساعت در تيمارهاى شاهد و

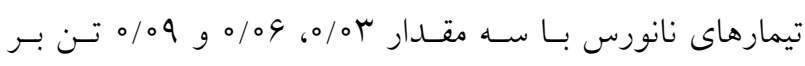

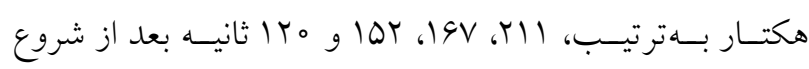
بارنـدگى بود. با توجه به شكل بم ميـانحين هـدررفت خـاك در تيمار شاهد و تيمارهاى حفاظتى نانورس با مقـادير مختلـف بـــ

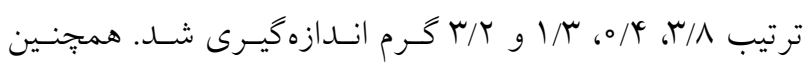
نتايج نشان داد كه بيشترين غلظت رسوب مربوط به تيمار شاهد

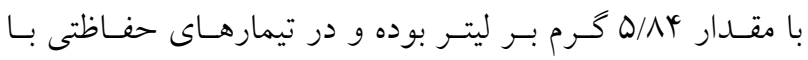



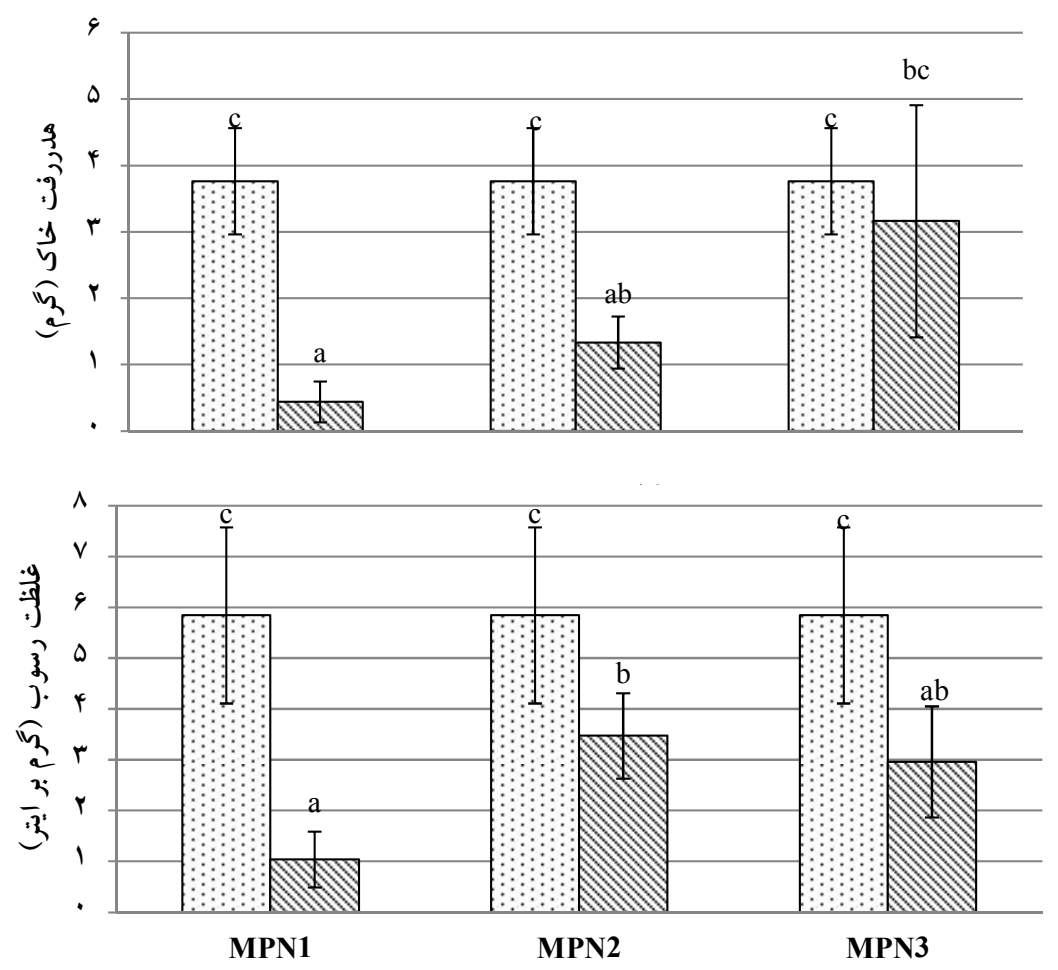

MPN3 و MPN2،MPNI

شكل r. الف) مقايسه ميانكين هدررفت خاك و ب) غلظت رسوب در تيمارهاى شاهد و نانورس مونتموريلونيت با مقادير مختلف

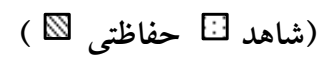

حفاظت آب و نفوذ آن به درون خـاك كـاهش يافـت. يكى از

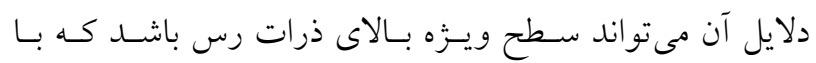

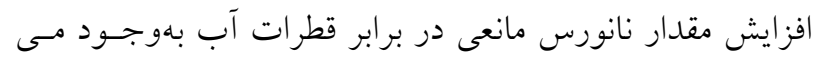

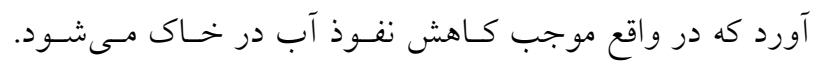

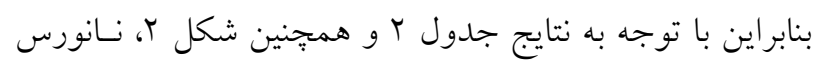

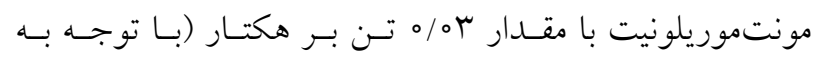

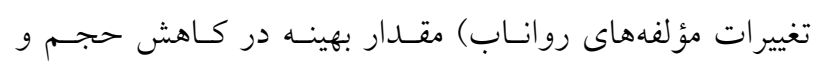
ضريب رواناب باشد. نتايج حاصل با نتايج بروغنسى و همكـاران

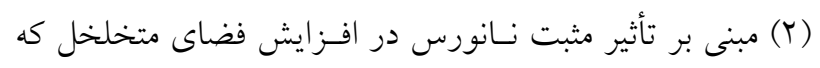

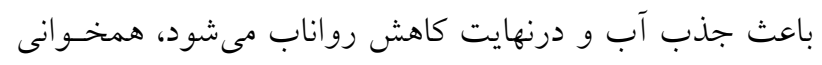

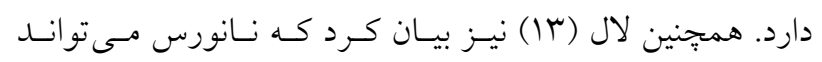

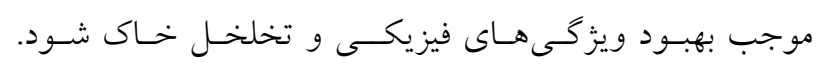

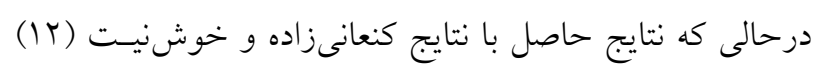

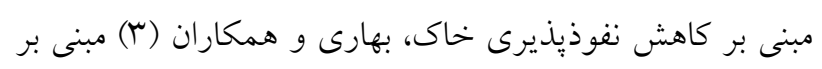

مقدار 9 \% هن بر هكتار نتوانست ضـريب روانـاب را كـاهش دهد و اثر افزايشى بر تغييرات اين متغير داشت (شكل r Y). نتايج

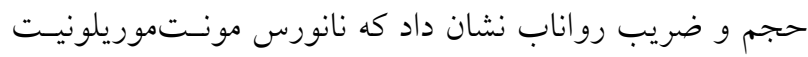

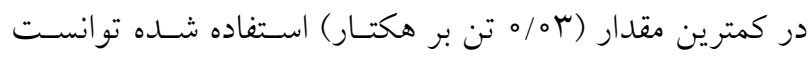

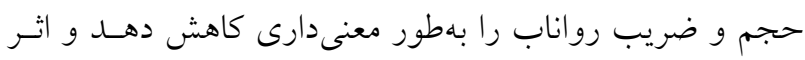

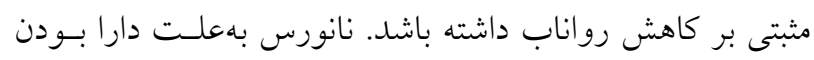

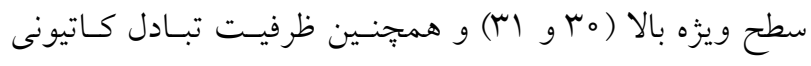

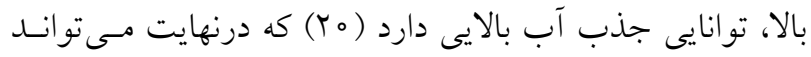

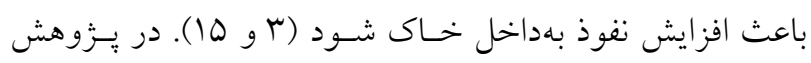

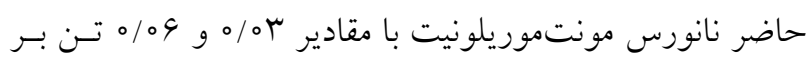

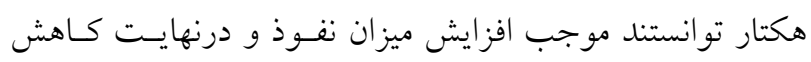

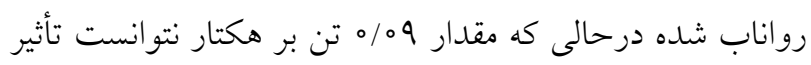

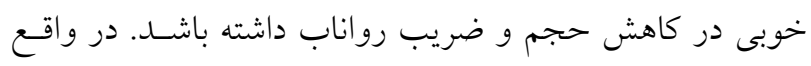

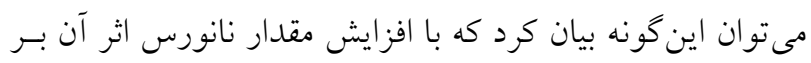


جدول س. نتايج آزمون GLM براى شناسايى اثرات تيمارهاى حفاظتى بر متغيرهاى رواناب و رسوب

\begin{tabular}{|c|c|c|c|c|c|}
\hline سطح معنى دارى & 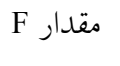 & ميانگين مربعات & درجه آزادى & مجموع مربعات نوع سوم & 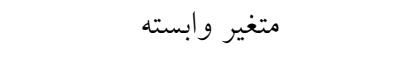 \\
\hline$\circ / \wedge$ & $r / r q$ & proo/ l & r & $1 r 900 / 9 r$ & زمان شروع رواناب (ثانيه) \\
\hline$\circ / \circ$ & $0 / Y I$ & $r \Delta \Delta \wedge \Delta \Delta / \Delta \varphi$ & r & VGVDG9/9V & حجم رواناب (ميلىليتر) \\
\hline$\circ / 0 Y$ & $0 / 09$ & WVG/4q & r & rmTq/4A & ضريب رواناب (درصد) \\
\hline.$/ 01$ & $1 / 99$ & $11 / \mathrm{N} 0$ & r & $r \Delta / 1 \circ$ & غلظت رسوب معلق (كرم در ليتر) \\
\hline.$/ 01$ & $v / \Gamma_{\circ}$ & $V / r)$ & r & $r \mid / 9 r$ & هدررفت خاى از كرت (گرم) \\
\hline
\end{tabular}

بيشترين ميزان كاهش غلظت رسوب در تيمار نانورس مونـت موريلونيت ب م/ه تن بر هكتـار نسـبت بـه تيمـار شـاهد بـود

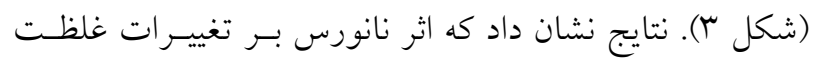
رسوب نيز در سطح 99 درصد معنى دار بود (جدول س). دانيلز

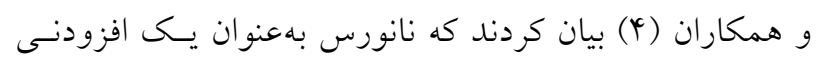
مى تواند افزايش فضاى متخلخل خاى شود، همجنين بِيدار و همكاران (1) نيز نشان دادند كه نانورس با افزايش خاصسيت جسبندكى در ذرات خاك مسى توانــ موجـب فرسـايش خـاى شود. درحالى كه با نتايج شريف نسب و عباسى (YV) مبنى بـر كاهش مقــار جسبند گیى ذرات خاك توسط نانورس، تاييوديـا و همكاران (rr) مبنى بر كاهش تراكميذّيرى خاك در اراضسى كشاورزى بعد از كاربرد نانورس مغايرت داشت. ايشـان دليـل اثرات منفى نانورس بر تجسبند گى ذرات خاك را ميزان و نـوع ذرات ريزدانه موجود در خـاك بيـان كردنـــ. درحسالى كـه در يزوهش حاضر اثرات مثبت نانورس بر كاهش هدررفت خـاك كزارش شد كه از دلايل اين كاهش وجود مقادير بيشـتر ذرات درشت خاى نسبت به مطالعـات تاييوديـا و همكـاران (بسان و شريفنسب و عباسى (YV) اسـت. از طرفىى نـانورس بـهدليـل نانورس بهدليـل داشـتن مسـاحت سـطح ويـزّه بسـيار حتى در

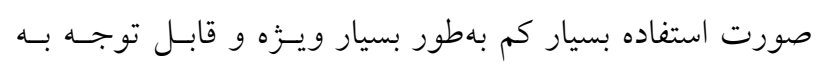
عنوان تثبيت كننده براى بهبود خو اص مكـانيكى خـاك اسـتفاده مىشود (Y)، بنابر اين با تثبيت خاك ميزان هدررفت خــاك نيـز كاهش خواهد يافت.
كاهش تخلخل، كاهش ضـريب نفوذيـذيرى و كـاهش هــايت هيدروليكى با توجه به نوع متفاوت خـاك از نظـر بافـت و نيـز

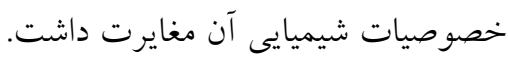
همان كونه كه نتايج نشـان مسىدهنــ بيشـترين و كمتـرين ميانخين هدررفت خاك خاك بهترتيب مربوط به تيمار شاهل و نانورس با مقدار به/ه تن بر هكتار بود. درحالى كه با افزايش

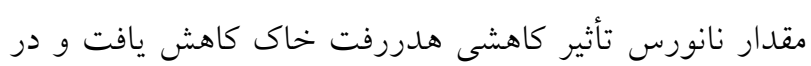

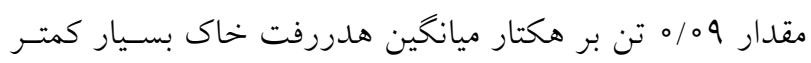
بود اما اثر هر سه مقدار نانورس بر تغييرات هدررفت خاك در سطح 99 درصد معنى دار بود (جدول r). تأثير معنىدار كاربرد نانورس مونتموريلونيت بر كاهش هدررفت خاك مسىتوانـد بهعلت دارا بودن سطح ويزه بالاى اين افزودنى بوده كه به اين دليل افزودنسى نـانورس مسى توانــ موجــب افـزايش خاصسيت جسبند گیى ذرات خاى شده (ه ا) درنتيجه ذرات جدا شـده از سطح خاى توسط فرايند باشمان و يا رواناب سطحى را بههم

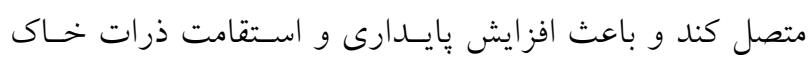

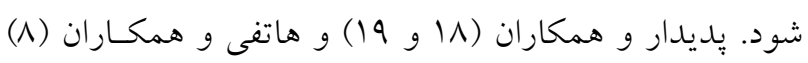
نشان دادند كـه بـا كـاربرد نـانورس در فرسـايش بـادى، ايسن افزودنى توانست تأثير زيادى در اتصال ذرات شن داشته باشد و درنتيجه مقدار ميزان فرسايش خاى را كاهش دهد. از طرفى عباسى و همكاران (1) بيان كردند كه نانورس بهعلت خاصيت

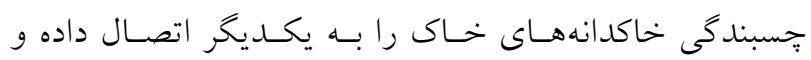
درنهايت بِانسيل بر اكندگى ذرات خاك را كاهش داد. همجِنين 


$$
\begin{aligned}
& \text { باشد. همجنين مى توان نتيجه كرفت كـه نـانورس استفاده شده }
\end{aligned}
$$

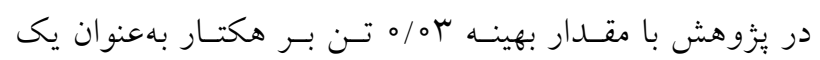

$$
\begin{aligned}
& \text { افزودنــــى باعث بهبـــــود خواص فيزيكى خاك مانند افزايش } \\
& \text { يايدارى و كاهش فرسايش و غلظت رسوب مىشـود كـه مسى } \\
& \text { توانـــ رهيـافتى در زمينـه اسـتفاده از ايــن افزودنــى بــوده و } \\
& \text { جايكزين مناسبى براى افزودنىهايى كه امكان استفاده آنهـا در } \\
& \text { خيلى از مناطق وجود ندارد باشد. درنهايت مسىتـوان بيشـنهاد } \\
& \text { كرد كه در شرايطى كه بحـث يـر شـــن مخــازن سـدها و نيـز } \\
& \text { اثرات شديد برون منطقهاى در فرسايش خاك وجود دارد و با } \\
& \text { توجه به اهميت حفاظت خاى در شرايط كشور ايران، نانورس } \\
& \text { بهاعنوان يك افزودنى مىتواند اثرات مناسبى در حفاظت خاك } \\
& \text { و آب داشته باشد. }
\end{aligned}
$$

\section{منابع مورد استفاده}

1. Abbasi, N. A. and S. Farjad Sepehri. 2017. The use of nanoclay particles for stabilization of dispersive clayey soils. Geotechnical and Geological Engineering 1-9.

2. Boroghani, M., S. Kh. Mirnia, J. Vahhabi and S. J. Ahmadi. 2014. Investigation of nanozeolite effects on soil erosion decreasing using FEL3 rainfall simulator. Journal of Watershed Management Research 9(5): 95-105.

3. Bahari, A., A. Sadeghinik, M. Roodbari, K. Taghavi and S. E. Mirshafiei. 2012. Synthesis and strength study of cement mortars containing sic nano particles. Digest Journal of Nanomaterials Biostructer 7: 1427-1435.

4. Daniels, J. M., P. Mehta, M. Vaden, D. Sweem, M. D. Mason, M. Zavareh and V. Ogunro. 2009. Nano- scale organo-silane applications in geotechnical and geo-environmental engineering. Journal of Terraspace Science and Engineering 1(1): 21-30.

5. Gholami, L., S. H. R. Sadeghi and M. Homaee. 2016. Different effects of sheep manure conditioner on runoff and soil loss components in eroded soil. Catena 139: 99-104.

6. Gholami, L., S. H. R. Sadeghi and M. Homaee. 2017. Splash erosion control using sheep manure. IASWS, 17-22 June 2017- Italy.

7. Grainger, A. 2014. Is land degradation neutrality feasible in dry areas? Journal of Arid Environments 112 (Part A): 14-24.

8. Hatefi, O., O. Jalalian, M. Padidar and J. Fallahzade. 2016. Effect of nanoclay on wind erosion a sandy loam soil in segzi region (Isfahan, Iran). Journal of Environmental Science and Technology 9(3): 296.

9. Khaledi Darvishan, A., V. Homainofar and S. H. R. Sadeghi. 2016. Designing, construction and calibration of a portable rainfall simulator for field runoff and soil erosion studies. Iran-Watershed Management Science and Engineering 10(34): 105-112. (in Farsi)

10. Kadivar, M., K. Barkhordari and M. Kadivar. 2011. Nanotechnology in geotechnical engineering. Advanced Materials Research 261: 524-528.

11. Kavian, A., L. Gholami, M. Mohammadi, V. Spalevic and M. Falah. 2018. Impact of wheat residue on soil erosion processes. Notulae Botanicae Horti Agrobotanici Cluj-Napoca 46(2): 543-553.

12. Kananizadeh, N. and A. Khoshniat. 2011. Behavior of nanoclay as an additive in order to reduce kahrizak landfill clay permeability. $2^{\text {nd }}$ International Conference on Environmental Science and Technology, Singapore.

13. Lal, R. 2008. Promise and limitations of soils to minimize climate change. Journal of Soil and Water Conservation 63(4): 113-118.

14. Majeed Z. H., M. R. Taha and L. T. Jawad. 2014. Stabilization of soft soil using nanomaterils. Research Journal of Appiled Sience, Engineering and Technology 8(4): 503-509.

15. Mohammadi, M. and M. Niazian. 2013. Investigation of nano-clay effect on geotechnical properties of Rasht clay. 
Journal of Advanced Science and Technology 3(3): 37-46.

16. Park, Y., G. A. Ayoko and R. L. Frost. 2011. Characterisation of organoclays and adsorption of p-nitrophenol: Environmental application. Journal of Colloid and Interface Science 360(2): 440-56.

17. Pimentel, D. and C. Harvey. 1999. Ecological effects of erosion. PP. 123-135. In: Walker, L. R. (eds), Ecosystems of Disturbed Ground.

18. Padidar, M., A. Jalalian, M. Abdouss, P. Najafi, N. Honarjoo and J. Fallahzade. 2014. Effect of nanoclay on soil erosion control. Nanocon 2014: 1-4.

19. Padidar, M., A. Jalalian, M. Abdouss, P. Najafi, N. Honarjoo and J. Fallahzade. 2016. Effets of nanoclay on some physical properties of sandy soil and wind erosion. International Journal of Soil Science 11: 9-13.

20. Quang, T., T. Nguyen and D. G. Baird. 2007. An improved technique for exfoliating and dispersing nanoclay particles into polymer matrices using supercritical carbon dioxide. Polymer 48: 6923-6933.

21. Roa-Espinosa, A., G. D. Bubenzer and E. S. Miyashita. 1998. Sediment and runoff control on construction sites using four application methods of polyacrylamide mix. 6p. Avaiable at: http://204.202.251.206/assets/114BPolymer.pdf.

22. Rostamdel, R., S. Ebrahimi and M. Zakernia. 2015. Study of crack curve of calcium, magnesium and chlorine from soil columns of sandy-montmorillonite nanoclay under treatment of sewage leachate with period. National Conference of Soil and Environment, 2-3 Septamber 2005.

23. Ruiz-Sinoga, J. D., A. Romero-Diaz, E. Ferre-Bueno and J. F. Martinez-Murillo. 2010. The role of soil surface conditions in regulating runoff and erosion processes on a metamorphic hillslope (Southern Spain) soil surface conditions, runoff and erosion in Southern Spain. Catena 80: 131-139.

24. Sadat Noori, S. A. and A. Khodayari. 2005. Review of Nanotechnology, Chapter 3. Noopardazan Book. (in Farsi).

25. Sadeghi, S. H. R. 2010. Study and Measurement of Water Erosion. Tarbiat Modares University Press, Iran. (in Farsi)

26. Sadeghi, S. H. R., Z. Abdollahi and A. Khaledi Darvishan. 2013. Experimental comparison of some techniques for estimating natural rain drop size distribution in Caspian Sea southern coast, Iran. Hydrological Sciences Journal 58(6): 1374-1382.

27. Sharifnasab, H. and N. Abbas. 2016. Effect of nanoclay particles on some physical and mechanical properties of soils. Journal of Agricultural Machinery (6): 250-258.

28. Spedding, I. 2005. Nanoclay- a New Beginning for Old Products. Director, Acme Nano Products Pty.

29. Taha M. R. and O. E. Taha. 2012. Influence of nano-material on the expansive and shrinkage soil behavior. Journal of Nanoparticle Research 14(10): 1-13.

30. Tassi, E., R. Pini, F. Gorini, I. Valadao and J. A. de Castro. 2012. Chemical and physical properties of soil influencing $\mathrm{Tio}_{2}$ nanoparticles availability in terrestrial ecosystems. Journal of Environmental Research and Development 6(4): 1034-1038.

31. Theron, J., J. A. Walker and T. E. Cloete. 2008. Nanotechnology and water treatment: applications and emerging opportunities. Critical Reviews in Microbiology 34(1): 43-69.

32. Taipodia, J., J. Dutta and A. K. Dey. 2011. Effect of nano-particles on properties of soil. Proceedings of the Indian Geotechnical Conference 15-17.

33. Zahedi, M., M. Sharifipour, F. Jahanbakhshi and R. Bayai. 2014. Nanoclay performance on resistance of clay under freezing cycles. Journal of Applied Sciences and Environmental Management 18(3): 427-434.

34. Zhang, G. 2007. Soil nanoparticles and their influence on engineering properties of soils. In Advances in Measurement and Modeling of Soil Behavior 1-13. 


\title{
Effect of Various Rates of Montmorillonite Nanoclay on Changing Runoff and Soil Loss
}

\author{
N. Hasanzadeh¹, L. Gholami ${ }^{*}$, A. Khaledi Darvishan ${ }^{2}$ and H. Yonesi ${ }^{3}$
}

(Received: September 25-2019; Accepted: September 9-2020)

\begin{abstract}
Soil erosion is one of the most serious environmental issues in the world, causing soil degradation, reduction of land productivity, increasing flood, water pollution and pollutions transportation; it is also a serious threat to sustainable development in the world. Therefore, the soil conservation and the prevention of soil erosion and use of conditioners as the nanoclay can be considered as a solution to improve land productivity and protect environment. The present study was, therefore, conducted to address the effect of the application of montmorillonite nanoclay with three rates of 0.03 , 0.06 and $0.09 \mathrm{t} \mathrm{ha}^{-1}$ on changing runoff and soil loss variables under laboratory conditions. The results showed that the nanoclay with the rate of $0.03 \mathrm{t} \mathrm{ha}^{-1}$ could decrease the runoff coefficient, soil loss and sediment concentration with the rate of $40.65,88.38$ and 82.19 percent, respectively. The average of soil loss in control treatment and conservation treatments of nanoclay with various rates was measured to be $3.76,0.44,1.33$ and $3.16 \mathrm{~g}$, respectively. Also, the results showed that the most sediment concentration was the control treatment with the rate of $5.84 \mathrm{~g} \mathrm{l}^{-1}$ and the conservation treatments with nanoclay in the applied rates was $1.04,3.47$ and $2.96 \mathrm{~g} \mathrm{l}^{-1}$, respectively. Also, the results showed that the nanoclay effect was significant on changing the soil loss and sediment concentration at the level of 99 percent. Finally, due to the effect, the use of this conditioner in natural conditions and investigation of the effects on environment and aggregates stability are recommended.
\end{abstract}

Keywords: Emerging Conditioners of Soil, Soil and Water Conservation, Sediment Concentration, Soil Erosion

1. Department of Watershed Management Engineering, College of Natural Resources, Sari Agricultural Sciences and Natural Resources University, Sari, Iran.

2. Department of Watershed Management Engineering, College of Natural Resources, Tarbiat Modares University, Noor, Iran.

3. Department of Environment Science, College of Natural Resources, Tarbiat Modares University, Noor, Iran.

Corresponding author, Email: 1.gholami@sanru.ac.ir 